\title{
THE CONCEPT OF WORK ETHIC IN ORDER TO IMPROVE THE QUALITY OF WORK IN ISLAMIC ECONOMIC PERSPECTIVE
}

\author{
Akhmad Hulaify \\ hulaify@gmail.com \\ Syahrani \\ syahrani.mm@gmail.com
}

Universitas Islam Kalimantan MAB Banjarmasin

\begin{abstract}
This research entitled the concept of work in improving the quality of work in perspective of Islamic economics. The orientation of ethic in the study of Islamic economics perspective is to discover work ethic of the essence of a work that expected to increase the quality of work. Based on the intention of this research, the author used sociology approach and normative approach. The aim of this research is to analyze how the study of wok ethics in Islamic economics perspective, it is expected that with those approach, this study can reveal the ethics values from Islamic law side. Beside of that, this study also discusses the result of research using qualitative descriptive analysis model. The analysis is meant to describe the meaning of work ethic not only in one economic point of view but from the perspective of Islamic Economics. Besides, the analysis is intended to get a new perspective to work ethics concept oriented to the essence of faith.

The conclusion of this research is manifestation of faith that implemented in the quality of work then work orientation will lack the sincere and good pleasure of Allah SWT. Therefore, the orientation of work is not only because material but ridha Allah SWT. If it has become a spirit in work the meaning of falah in the concept of Islamic Economy is realized and fulfilled.
\end{abstract}

Keywords:Ethis, Works, Quality, Islamic Economics.

\section{PENDAHULUAN}

Etos kerja dewasa ini telah menjadi satu komoditas perbincangan ditegah masyarakat kita, bahkan menjadi ajang kajian akademik di dunia perguruan tinggi. Hal ini bukan sematamata karena tanpa alasan tapi karena kegalauan para kaum intelektual, bahwasannnya jika bangsa Indonesia tidak mampu menumbuhkan etos kerja yang berkualitas maka akan ada kemungkinan negara Indonesia akan tetap tertinggal oleh negara-negara berkembang lainnya. Bahkan tanpa terkecuali oleh negara tetangga di lingkungan Asia Tenggara, terlebih asia Timur. Tidak salah jika muncul sebuah ramalan yang bernada pesimis bahwa jika kita tidak berhasil menjadi negara maju maka dalam waktu kurangdari 1/4 abad yang akan datang, ketika seluruh asia timur telah menjadi negara indutri, indonesia hanya tidak lebih negara back yard kawasan asia. 
Dalam sabda nabi juga diisyaratkan bahwa seorang muslim harus bekerja dengan niat memperoleh ridlah Allah dan Rasul-nya. Sudah barang tentu hal tersebut merupakn standarisasi ajaran Islam. Dengan demikian jelas bahwa nilai ibadah pun akan hilang kebaikannya yang intrinsik karena motivasi pelakunya rendah. Jadi kerja tanpa nilai ketawabduan tidak akan memberi kebahagian keberkahan kepada pelakunya.Kerja atau amal adalah bentuk keberadaan(mode of exstence) manusia. Artinya manusia ada karena kerja dan karena kerja itulah yang membuat atau mengisi eksistensi kemanusiaannya. Karena itu Rene Descartes, seorang filosuf dari prancis pada masa renainses, mengatakan, "aku berpikir, maka aku ada"(cagito ergo sum) karena baginya berpikir merupakan wujud dari manusia itu sendiri. Pandangan ini sangat sentral dalam ajaran Islam. Ditegaskan bahwa manusia tidak akan mendapat sesuatu apa pun melainkan dari usahanya sendiri :

$$
\text { Itulah Yang dimaksudkan }
$$
bahwa kerja merupakan bentuk manusia menunjukan eksistensi manusia itu sendiri. Manusia akan ternilai dimata Tuhannya karena amal dan dengan amal itulah manusia ada dan amalan yang baik akan mengangkat manusia kederajat yag setinggi-tingginya yaitu bertemu uhan dengak kerilaan. "barang siapa benar- benar mengharapkan bertemu degan Tuhannya maka hendakal ia berbuaat baik dan hendaklah ketika beribadah kepada Tuhan dia tidak melakukan kesyirikan(yakni mengalihkan tujuan pekerjaan kepada selain Allah" Sang Maha Benar, al-haqq yang menajdi sumber nilai intrinsik pekerjaan manusia.

Seperti yang telah disampaikan di atas bahwa ajran Islam dalam konteks kerja dapat dipandang secara taken for granted oleh orang- orang muslim. Tapi lagi -lagi implikasi dari ajaran itu patunjuk untuk kita renungkan secara medalam. Kalau manusia dibedakan dengan manusia lainya dari amal yang diperbuatnya, maka dari itu hendaklah ia tidak mengangap tenteng dari setiap amal yang ia kerjakan, ia harus memberi makna setiap pekerjaan yang ia lakukan, sehingga amalanya menjadi bagian yang integral makna hidupnya lebih menyeluruh. Amal sebagai bentuk keberadaan dirinya, baik dan buruk dari amalnya kan membentuk kepribadiannya. Hal yang keliru ketika mengapa pekerjaan yang ia lakukan 
untuk orang lain dalam konteks eksistensinya, karena setiap amal untuk dirinya sendiri. Bahkan demi menjaga kekokohan nilai intrinsiknya, harus diorentasikannya kepada Tuhan sama hanya dengan melakukan jihad $f i$ sbililah

\section{METODE PENELITIAN}

Penelitian ini kalau dilihat dari jenisnya termasuk penelitian kualitatif yang mengacu kepada data pustaka. Kemudian orientasi dari penelitian ini bertitik tolak dari penekanan pada proses dan makna. Teori dimanfaatkan sebagai pemandu agar penelitian lebih fokus dan sesuai dengan fakta di lapangan. Selain itu, landasan teori juga bermanfaat untuk memberikan gambaran umum tentang latar penelitian dan sebagai bahan pembahasan hasil penelitian. Dalam penelitian kualitatif peneliti bertolak dari data yang ada, memanfaatkan teori yang ada sebagai bahan penjelas, dan berakhir dengan suatu "teori”. Sifat dari penelitian ini adalah deskriftif. Kondisi ini mengacu kepada orientasi data yang menjadi sumber utama penelitian ini. Dimana sumber utama adalah mengacu kepada buku-buku teks dan yang terhubung secara langsung maupun tidak langsung dengan penelitian ini.
Pendekatan merupakan sebuah alat yang digunakan untuk melihat secara mendalam permasalah (phenomena) yang ada di lapangan. Kalau dilihat dari sifat dan jenis dari penelitian ini maka pendekatan yang digunakan ada dua yaitu Pendekatan Sosiologis dan Pendekatan Normatif. Pendekatan yang pertama pendekatan sosiologis. Pendekatan ini tentunya sangatlah mendukung untuk memperhatikan secara seksama tentang realitas perkembangan dunia etos kerja di masyaka. Realitas tersebut nantinya diharapkan mampu untuk menjawab permasalah dengan sudut padang dalam Ekonomi dunia Syariah.Pendekatan yang kedua yaitu pendekatan normatif. Alasan mengapa penelitian menggunakan pendekatan normatif dikarenakan penelitian ini beroreintasi pada asas-asas hokum dalam konteks ekonomi. Berawal dimana penelitian ini bertitik tolak dari kejadian yang berkembang di lapangan terkait pembahasan Etos kerja dalam meningkatkan kualitas kerja dan kometmen dalam sebuah organisasi yang mengemban tugas bersama guna mewujudkan keadilan dan kebersamaan dalam meraih keridhaan Allah di dunia dan di Akhirat 
Analisa data merupakan proses pengorganisasian dan pengaturan secara sistematik sejumlah data ke dalam pola, kategori dan satuan uraian dasar sehingga dapat ditemukan tema dan hipotesis kerja seperti yang disarankan data, dan untuk meningatkan pemahaman terhadap bahan-bahan tersebut untuk dipresentasikan kepada orang lain. Teknik analisa data yang digunakan dalam penelitian ini adalah analisis “Komparatif Interpretatif”, yaitu metode analisa data dengan cara melakukan perbandingan terhadap suatu fokus dari berbagai basis paradigma yang berbeda, dan selanjutnya membuat kesimpulan-kesimpulan berdasarkan perbandingan-perbandingan tersebut secara interpretatif.

Sebagai sebuah Ilmu, maka ekonomi Syariah sangatlah luas. Ekonomi Syariah bisa merupakan bagian integral dari islam itu sendiri bisa juga merupakan ilmu ekonomi yang ditinjau dari sudut pandang Syariah. Disini tidak akan dipersoalkan dari sisi mana ekonomi Syariah tersebut dilihat. Dalam ilmu ini bisa dipelajari bagaimana adanya atau bagaimana seharusnya perilaku ekonomi masyarakat muslim, untuk memenuhi kebutuhan hidupnya dengan tetap mengikuti syari'at-syariat Islam sebagai pegangan hidupnya dalam kerangka Etos Kerja.

\section{PEMBAHASAN}

ETOS KERJA DALAM PANDANGAN ISLAM

Perspektif Sosiologi agama,ditemukan istilah "agama etika"atau ethical Religion, yakni agama yang mengajarkan (dalam sistem teologisnya) bahwa keselamatan manusia diperoleh melalui kegiatan atau amal perbuatan yang berbudi luhur. Islam termasuk kelompok agama etika ini. Bahkan seorang ahli menyebutnya sebagai "monoteisme etis" (ethical monotheisme)(Majid, 1994).Islam mengajarkan bahwa cara seseorang mendekati Tuhan ialah dengan berbuat baik (beramal saleh) dan mengabdi kepada Tuhan dengan tulus. Orientasi kerja ini merupakan perombakan fundamental terhadap orientasi keturunan pada bangsa Arab sebelum Islam. Karena itu, Ibn Taimiyah mengatakan, al-i'tibâr fí al-jâhiliyyah bi al-ansâb, wa ali'tibâr fí al-Islâm bi ala'mâl (penghargaan dalam jahiliyyah berdasarkan keturunan, dan penghargaan dalam Islam berdasarkan kerja).(Majid, 1994). 
Volume 4 Nomor 1, April 2018

Secara teoritis, pengkajian danpenelitian tentang relasi antara agama secara umum dengan etos kerja ini memang melahirkan satu teori ilmu besar (grand theory) yang disebut teori fungsional. Teori ini berpandangan bahwa fungsi agama adalah mendukung dan melestarikan masyarakat yang sudah ada. Karena itu, agama bersifat fungsional terhadap persatuan dan solidaritas sosial.(Husein, 1995).Salah satu tokoh besar dari aliran ini adalah Max Weber. Dalam buku Mognum Opusnya yang berjudul The Protestant Ethic and the Spirit of Capitalism, dia menyatakan adanya korelasi positif antara agama Kristen Protestan dengan etos kerja dalam membangun dan mengembangkan

kapitalisme.(Jalaluddin, 1996)

Teori ini kemudian diuraikan secara lebih mendetail dalam karya Taufiq Abdullah (ed.), Agama, Etos Kerja dan Perkembangan Ekonomi (Jakarta: LP3ES, 1979). Buku yang memuat beberapa tulisan dari sejumlah penulis yang berbeda luar maupun dalam negeri, memberikan gambaran secara lengkap mengenai pemikiran dan kerangka teoritis Max Weber mengenai teori fungsional. Di antara mereka adalah Taufiq Abdullah, "Tesis Weber dan Islam di Indonesia; Max Weber, "Sekte-sekte Protestan dan Semangat Kapitalisme"; Max Weber, "Sikap Agama-agamaDunia Lain terhadap Orde Sosial dan Ekonomi"; Bryan S. Turner, "Islam, Kapitalisme dan Tesis Weber"; dan Hussein Alatas, "Tesis Weber dan Asia Tenggara". Selain itu, untuk memperkuat aspek teoritis mengenai relasi agama dan etos kerja, buku ini juga memuat tulisan Clifford Geertz, dengan judul "Perubahan Sosial dan Modernisasi Ekonomi di Dua Kota Indonesia". Kumpulan tulisan yang terdapat dalam buku ini selainbanyak memberikan landasan pemikiran, juga mengkritisi teori Weber sebagai salah satu alternatif pemikiran yang bisa dijadikan landasan penerapannya di agama-agama lain.Dengan menggunakan asumsi yang sama mengenai relasi agama dan etos kerja, mengembangkan kajian Islam dan etos kerja dari perspektif tasawuf.Dalam kajian tasawuf, posisi manusia terhadap kerja dapat dibagi ke dalam dua kategori. Pertama, orang yang berada di maqâm tajrîd, yakni orang-orang yang posisinya sudah tidak lagi membutuhkan kerja. Ini terjadi karena beberapa factor, seperti sudah lanjut usia, terlalu kecil melakukan pekerjaan, atau mungkin 
Volume 4 Nomor 1, April 2018

orang tersebut telah memiliki satu tingkat tertentu dalam hidupnya sehingga tidak menginginkan berbagai kesenangan yang mengharuskannya kerja. Kategori kedua, orang yang berada pada maqâm ikhtiyâr, yakni mereka yang masih membutuhkan kerja karena masih memerlukan rumah, kendaraan dan kebutuhan-kebutuhan lainnya. Dalam konteks ini, Tholchah Hasan melakukan kontekstualisasi kategori maqâm ikhtiyâr untuk mengembangkan etos kerja dalam Islam(Jalaluddin, 1996)Disisi lain, dalam tradisi filsafat, istilah "etika" lazim dipahami sebagai teori ilmu pengetahuan yang mendiskusikan mengenai apa yang baik dan apa yang buruk berkenaan dengan perilaku manusia. Dengan kata lain, etika merupakan usaha dengan akal budinya untuk menyusun teori mengenai penyelenggaraan hidup yang baik. Nilainilai etis yang dipahami, diyakini,dan berusaha diwujudkan dalam kehidupan nyata kadangkala disebut sebagai etos.(Rachman, 1994)Dalam hubungan ini, etos berhubungan erat dengan pandangan-dunia (worldview) atausistem nilai yang dipegang oleh sebuah masyarakat.(Martin, 1982)
Kemudian Clifford Geertz berasumsi, etos adalah the underlying attitude toward themselves and their world that life reflects (sikap yang mendasar terhadap diri dan dunia yang dipancarkan dalam hidup). Etos adalah aspek evaluatif, yang bersifat menilai.(Abdullah, 1979) Berkenaan dengan etos kerja, banyak para ahli telah mendefinisikan etos kerja ini sebagai "sebuah sikap mendasar dan ide pokok yang senantiasa berpengaruh besar terhadap kerja." Etos kerja berarti sikap yang mendasar tentang kerja pada diri seseorang. Setiap manusia memiliki spirit untuk sukses, ruhkeberhasilan, yakni motivasi murni untuk meraih dan menikmati keberhasilan. Spirit inilah yang mengejawantah menjadi perilaku yang khas, seperti kerja keras, disiplin, teliti, tekun, integritas, rasional dan bertanggungjawab melalui keyakinan, komitmen danpenghayatan atas paradigma kerja tertentu seperti "kerja adalah rahmat", "kerja adalah amanah", "kerja adalah ibadah".(Abdullah, 1979)

Salah satu teori yang relevan bahwa etos kerja terkait dengan sistem kepercayaan yang diperoleh karena pengamatan bahwa masyarakat tertentudengan sistem kepercayaan tertentu memiliki etos kerja lebih baik 
atau lebih buruk dari masyarakat lainnya. Sebagai contoh, yang paling terkenal adalah pengamatan sosiolog Max Weber terhadap masyarakat Protestan aliran Calvinisme(Rachman, Esiklopedia Nurcholis Majid, 2006)yang diangkat menjadi dasar apa yang disebut "Etika Protestan". Para peneliti lainnya, juga melihat gejala yang sama pada masyarakatmasyarakat dengan sistem kepercayaan yang berbeda. Misalnya, masyarakat Tokugawa di Jepang oleh Robert N. Bellah, komunitas santri di Jawa dan masyarakat Hindu Brahmana di Bali oleh Clifford Geertz. Semua tesis ini bertitik tolak dari sudut pandang nilai, atau dalam bahasa agama bertitik tolak dari keimanan. Max Weber sendiri mencetuskan ide etos kerja sebagai aspek evaluatif yang bersifat penilaian diri terhadap kerja yang bersumber dari realitas spiritual keagamaan yang diyakininya. Selanjutnya dijelaskan bahwa cara hidup yang sesuai dengan kehendak Tuhan adalah memenuhi kewajiban yang ditimpakan kepada si individu oleh kedudukannya di dunia. Inilah yang disebut sebagai calling atau panggilan, sebuah konsepsi agama mengenai tugas yang ditentukan oleh Tuhan, sebuah tugas hidup dan lapangan yang jelas tempat ia bekerja.(Abdullah,
1979) sejalan dengan tesis Weber ini, etos kerja dalam Islam adalah hasil suatu kepercayaan seorang Muslim bahwa kerja memiliki kaitan dengan tujuan hidup, yakni memperoleh ridha Allah Swt. Ini adalahimplementasi dari kenyataan bahwa Islam adalah agama amal atau kerja (praxis) yang mengajarkan "orientasi kerja" (achievement orientation).

Dalam kerangka ajaran Islam, maka konsep inner-worldlyasceticism ini tidak terletak pada "panggilan" untuk menjadi diri manusia sebagai orang terpilih, namun pada kemutlakan Islami pada setiap ...Muslim untuk melaksanakan kewajiban ibadah dan mu'âmalah secara simultan dan hanya kepada mereka yang bekerja akan diberikan balasan keduniawiannya (QS. Al-Baqarah [2]: 202). Karena itu, kesalehan tidak hanya bermakna menjauhkan diri dari dunia (outworldyasceticism) namun juga bermakna mencurahkan diri dalam kegiatan-kegiatan keduniaan, termasuk kegiatan ekonomi (inworldy asceticism).(Pranomo, 1992)

Kesalehan macam ini misalnya menjiwai keulaten dalam aktivitas ekonomi sebagai media dakwah dan mendekatkan diri kepada Allah Swt. 
Ditinjau dari berbagai sisi dalam sistem nilai Islam maka dapat ditegaskan bahwa ajaran Islam memberikan kondisi spiritual (psychological dynamics) kepada umat Islam untuk melakukan aktivitas keduniawian yang memiliki makna religius. Dalam hal ini, surah $A l$ Dhûha bisa menjadi sumber etos kerja yang baik karena tiga alasan. Pertama, ada tuntutan bahwa kita harus berorientasi ke masa depan; kedua, kita harus optimis bahwa akan ada kemenangan di masa depan sebagai wujud dari ganjaran (reward) pekerjaan kita sendiri; ketiga, ada tuntutan agar kita tetap tawaddlu dan tahu diri sehingga tidak menjadi sombong.(Rahman B. M., 2006)

\section{ETOS KERJA DALAM KARANGKA MENINGKATKAN KUALITAS KERJA DALAM PANDANGAN EKONOMI SYARIAH}

Umat Islam adalah umat yang beruntung karena semua pedoman dan panduan sudah terkodifikasi. Kini tinggal bagaimana menterjemahkan dan mengapresiasikannya dalam kegiatan harian, mingguan dan bulanan. Jika kita pandang dari sudut bahwa tujuan hidup itu mencari Ridha Allah SWT maka apapun yang dikerjakannya, apakah di rumah, di kantor, di ruang kelas, di perpustakaan, di ruang penelitian ataupun dalam kegiatan kemasyarakatan, takkan lepas dari kerangka tersebut.

Khasanah Islam mungkin bisa dikaitkan dengan padanan kata ihsan. Setiap manusia, seperti diungkapkan Al Qur'an, diperintahkan untuk berbuat ihsan agar dicintai Allah. Kata Ihsan sendiri merupakan salah satu pilar disamping kata Iman dan Islam. Dalam pengertian yang sederhana, ihsan berarti kita beribadah kepada Allah seolah-olah Ia melihat kita. Jikalau kita memang tidak bisa melihat-Nya, tetapi pada kenyataannya Allah menyaksikan setiap perbuatan dan desir kalbu kita. Ihsan adalah perbuatan baik dalam pengertian sebaik mungkin atau secara optimal. Hal itu tercermin dalam Hadis Riwayat Muslim yang menuturkan sabda Rasulullah SAW :

"Sesungguhnya

Allah

mewajibkan ihsan atas segala sesuatu. Karena itu jika kamu membunuh, maka berihsanlah dalam membunuh itu dan jika kamu menyembelih, maka berihsanlan dalam menyembelih itu dan hendaknya seseorang menajamkan pisaunya dan menenangkan binatang sembelihannya itu."

Menurut Nurcholis Madjid, dari konteks hadis itu dapat disimpulkan 
bahwa ihsan berarti optimalisasi hasil kerja dengan jalan melakukan pekerjaan itu sebaik mungkin, bahkan sesempurna mungkin. "Penajaman pisau untuk menyembelih" itu merupakan isyarat efisiensi dan daya guna yang setinggitingginya. Allah mewajibkan ihsan atas segala sesuatu seperti tercermin dalam Al Qur'an. Yang membuat baik, sebaikbaiknya segala sesuatu yang diciptakanNya. Selanjutnya Allah juga menyatakan telah melakukan ihsan kepada manusia, kemudian agar manusia pun melakukan ihsan. Dan carilah apa yang dianugerahkan kepadamu (kebahagiaan) negeri akhirat, dan janganlah kamu melupakan kebahagiaan dunia, dan berbuat ihsanlah kepada orang lain sebagaimana Allah telah berbuat ihsan kepadamu, dan janganlah kamu berbuat kerusakan di muka bumi. Sesungguhnya Allah tidak menyukai orang-orang yang berbuat kerusakan.

Sebagai agama yang menekankan arti penting amal dan kerja, dalam kajian Ekonomi Syariah mengajarkan bahwa kerja itu harus dilaksanakan berdasarkan beberapa prinsip berikut:

1. Bahwa perkerjaan itu dilakukan berdasarkan pengetahuan sebagaimana dapat dipahami dari firman Allah dalam al-Qurean, "Dan janganlah kamu mengikuti sesuatu yang kamu tidak mempunyai pengetahuan mengenainya."(QS, 17: 36).

2. Pekerjaan harus dilaksanakan berdasarkan keahlian sebagaimana dapat dipahami dari hadis Nabi Saw, "Apabila suatu urusan diserahkan kepada bukan ahlinya, maka tunggulah saat kehancurannya." (Hadis Shahih riwayat al-Bukhari).

3. Berorientasi kepada mutu dan hasil yang baik sebagaimana dapat dipahami dari firman Allah, "Dialah Tuhan yang telah menciptakan mati dan hidup untuk menguji siapa di antara kalian yang dapat melakukan amal (pekerjaan) yang terbaik; kamu akan dikembalikan kepada Yang Maha Mengetahui yang ghaib dan yang nyata, lalu Dia memberitahukan kepadamu tentang apa yang telah kamu kerjakan." (QS. Al-Mulk: 67: 2). Dalam Islam, amal atau kerja itu juga harus dilakukan dalam bentuk saleh sehingga dikatakan amal saleh, yang secara harfiah berarti 
sesuai, yaitu sesuai dengan standar mutu.

4. Pekerjaan itu diawasi oleh Allah, Rasul dan masyarakat, oleh karena itu harus dilaksanakan dengan penuh tanggung jawab, sebagaimana dapat dipahami dari firman Allah, "Katakanlah: Bekerjalah kamu, maka Allah, Rasul dan orang-orang beriman akan melihat pekerjaanmu.”(QS. 9: $105)$.

5. Orang berhak mendapatkan imbalan atas apa yang telah ia kerjakan. Ini adalah konsep pokok dalam agama. Konsep imbalan bukan hanya berlaku untuk pekerjaan-pekerjaan dunia, tetapi juga berlaku untuk pekerjaanpekerjaan ibadah yang bersifat ukhrawi. Di dalam alQur"an ditegaskan bahwa: "Allah membalas orang-orang yang melakukan sesuatu yang buruk dengan imbalan setimpal dan memberi imbalan kepada orangorang yang berbuat baik dengan kebaikan."(QS. 53: 31). Dalam hadis Nabi dikatakan, "Sesuatu yang paling berhak untuk kamu ambil imbalan atasnya adalah Kitab Allah." (H.R. al-Bukhari). Jadi, menerima imbalan atas jasa yang diberikan dalam kaitan dengan Kitab Allah; berupa mengajarkannya, menyebarkannya, dan melakukan pengkajian terhadapnya, tidaklah bertentangan dengan semangat keikhlasan dalam agama.

6. Ajaran Islam menunjukkan bahwa "kerja" atau "amal" adalah bentuk keberadaan manusia. Artinya, manusia ada karena kerja, dan kerja itulah yang membuat atau mengisi keberadaan kemanusiaan. Jika filsuf Perancis, Rene Descartes, terkenal dengan ucapannya, "Aku berpikir maka aku ada" (Cogito ergo sum) karena berpikir baginya bentuk wujud manusia- maka sesungguhnya, dalam ajaran Islam, ungkapan itu seharusnya berbunyi "Aku berbuat, maka aku ada."(Majid N. , 1992) Pandangan ini sentral sekali dalam sistem ajaran Islam. Ditegaskan bahwa manusia tidak akan mendapatkan sesuatu apa pun kecuali yang ia usahakan sendiri: "Belumkah ia (manusia) diberitahu tentang apa yang ada dalam lembaranlembaran suci (Nabi (Musa)? Dan Nabi Ibrahim yang setia? Yaitu bahwa seseorang yang berdosa tidak akan 
Volume 4 Nomor 1, April 2018

menanggung dosa orang lain. Dan bahwa tidaklah bagi manusia itu melainkan apa yang ia usahakan. Dan bahwa usahanya itu akan diperlihatkan (kepadanya), kemudian ia akan dibalas dengan balasan yang setimpal. Dan bahwa kepada Tuhanmu lah tujuan yang penghabisan"(QS.52:36-42). Itulah yang dimaksudkan dengan ungkapan bahwa, kerja adalah bentuk eksistensi manusia. Yaitu bahwa harga manusia, yakni apa yang dimilikinya tidak lain ialah amal perbuatan atau kerjanya itu. Manusia ada karena amalnya, dengan amalnya yang baik itu manusia mampu mencapaiharkat yang setinggi-tingginya, yaitu bertemu Tuhan dengan penuh keridlaan. "Barang siapa benarbenar mengharap bertemu Tuhannya, maka hendaknya ia berbuat baik, dan hendaknya dalam beribadat kepada Tuhannya itu ia tidak melakukan syirik,'QS.18: 110 (yakni, mengalihkan tujuan pekerjaan selain kepada Allah, Sang Maha Benar, al-Haqq, yang menjadi sumber nilai terdalam pekerjaan manusia).
7. Menangkap pesan dasar dari sebuah hadis shahih yang menuturkan sabda Rasulullah Saw yang berbunyi "Orang mukmin yang kuat lebih disukai Allah”, redaksinya kira-kira begini: "Orang mukmin yang kuat lebih baik dan lebih disukai Allah" azza wa jalla dari pada orang mukmin yang lemah, meskipun pada kedua-duanya ada kebaikan. Perhatikanlah hal-hal yang bermanfaat bagimu, serta mohonlah pertolongan kepada Allah, dan janganlah menjadi lemah. Jika sesuatu (musibah) menimpamu, maka janganlah berkata: "Andaikan aku lakukan sesuatu, maka hasilnya akan begini dan begitu". Sebaliknya berkatalah: "Ketentuan (qadar) Allah, dan apa pun yang dikehendaki-Nya tentu dilaksanakan-Nya". Sebab sesungguhnya perkataan "andaikan" itu membuka perbuatan setan".(Mukhtasar Shaih Muslim, 1969)

Dengan beberapa kajian teori ekonomi syariahdi atas, dapatlah dikenali bebarapa kreteria khusus dalam etos kerja sebagai karangka meningkatkan kualitas kerja ekonomi syariah adalah sebagai berikut: 
1. Menghargai waktu

Salah satu hakekat dari etos kerja adalah cara seseorang menghayati, memahami, dan dan merasakan bertapa berharganya waktu. Satu detik berlalu tidak mungkin ia kembali. Waktu merupakan deposito yang paling berharga yang dianugrahkan Allah SWT secara gratis dan merata kepada setiap orang. Tergantung kepada masingmasing manusia bagai mana mereka memanfaatkannya depositonya tersebut. Seorang muslim berkata bahwa waktu adalah kekuatan, baginya waktu adalah aset Ilahiah yang sangat berharga, adalah ladang subur yang membutuhkan ilmu dan amal untuk di olah serta dipetik hasilnya pada waktu yang lain. (Abdullah M. , 2011)Untuk itulah disadari oleh setiap muslim memang apa yang akan diraih pada waktu yang akan datang ditentukan oleh caranya mengadakan pada hari ini.

2. Berpegang Teguh dengan Kejujuran Dalam jiwa seorang yang jujur itu terdapat komponen nilai ruhani yang memantulkan berbagai sikap yang berpihak kepada kebenaran dan sikap moral yang terpuji.
Dirinya telah dibelenggu, dikuasai dan di perbudak oleh kejujuran. Dia merasa bangga menjadi budak Allah (abdullah). Dia merasa merdeka karena terpenjara oleh kejujuran. Tindakan yang menyimpang dari nilai ruhani kejujurannya itu berarti dia telah menghianati diri dan keyakinannya sendiri. Orang yang tidak jujur berarti menipu dirinya sendiri di hadapan Allah. Sebagaimana keihlasan, kejujuran tidak datang dari luar, tetapi dari bisikan kalbu yang terus menerus mengetuk-ngetuk dan membisikan nilai moral luhur yang didorong gelora cinta yang meng-illahi. Kejujuran bukan sebuah keputusan, melainkan sebuah panggilan dari dalam, sebuah keterikatan.

3. Memiliki Komitmen (Aqidah, Aqad dan Itiqa)

Dalam komitmen tergantung sebuah tekad, keyakinan, yang melahirkan bentuk vitalitas yang penuh gairah. Mereka yang memiliki komitmen tidak mengenal kata menyerah. Mereka hanya akan berhenti menepikan cita-citanya, jalanya yang lurus, dan langit sudah runtuh. Komitmen adalah soal tindakan, keberanian. Komitmen bukan 
komat, kamit, kemot dan kumat.

Komitmen adalah soal kesungguhan kesinambungan.

4. Istiqomah, Kuat Pendirian Pribadi muslim yang profesional dan berakhak memiliki sikap konsisten yaitu kemampuan untuk bersikap secara taat asas, pantang menyerah, dan mampu mempertahankan prinsip serta komitmennya walau harus berhadapan dengan resiko yang membahayakan dirinya.

5. Konsekuen dan Berani Menghadapi Tantangan

Ciri lain dari pribadi muslim yang memiliki budaya kerja adalah keberaniannya menerima konsekuensi dari keputusannya. Bagi mereka, hidup adalah pilihan dan setiap pilihan merupakan tanggung jawab pribadinya. Mereka tidak mungkin menyalahkan pihak manapun karena pada akhirnya semua pilihan ditetapkan oleh dirinya sendiri. Rasa tanggung jawabnya mendorong prilakunya yang bergerak dinamis, seakan-akan di dalam dadanya ada "nyala api", sebuah motivasi yang kuat untuk mencapai tujuan dan menjaga apa yang telah menjadi keputusan atau pilihannya. Orang yang konsekuen mempunyai kemampuan untuk

melakukan pengendalian dan mengelola emosinya menjadi penggerak positif untuk tetap semangat menapaki keyakinannya.

6. Kreatif

Pribadi muslim yang kreatif selalu ingin mencoba metode gagasan baru sehingga diharapkan hasil kinerja dapat dilaksanakan secara efisien, tetapi efektif. Mereka yang beragama Islam sangat memahami ayat pertama yang diterima Rasulullah SAW, yaitu kata Iqra' yang berarti tidak hanya dalam pengertian membaca, tetapi juga mengumpulkan dan merangkum data menjadi satu arti. Seorang kretaif pun bekerja dengan informasi, data, dan mengolahnya sedemikian rupa sehingga memberikan hasil atau manfaat yang besar. (Tasmara, 2002)

7. Bahagia dalam Melayani Melayani atau menolong seseorang merupakan bentuk kesadaran dan kepedulian terhadap nilai kemanusiaan. Memberi pelayanan dan pertolongan merupakan investasi yang kelak akan dipetik keuntungannya, tidak hanya 
diakhirat, tetapi di dunia pun mereka sudah merasakannya.

8. Memiliki Jiwa Kepemimpinan Kepemimpinan berarti kemampuan untuk mengambil posisi dan sekaligus memainkan peran sehingga kehadiran dirinya memberikan pengaruh pada lingkungannya. Seorang pemimpin adalah seorang yang mempunyai personalitas yang tinggi. Dia larut dalam keyakinannya, tetapi tidak segan untuk menerima kritik bahkan mengikuti apa yang terbaik.

9. Memperkaya jaringan silaturrahmi

Pribadi yang memiliki etos kerja akan menjadikan silaturahmi sebagai salah satu ruh pengembangan dirinya. Karena bukan saja memiliki nilai ibadah yang bernilai ukhrawi, tetapi hasilnya juga dapa dipetik di dunia. Dia akan menduniakan nilai akhiratnya dan mengakhiratkan nilai duniawinya dengan bersilaturahmi. Hanya manusia yang hidup dan ingin menghidupkan dirinya yang sangat peduli dengan silaturahhmi. Mereka memandang setiap pribadi manusia adalah “ fakultas kehidupan”. Dari orang lain, dia akan belajar tentang pengalamnan yang tidak dia peroleh di bangku sekolah. Silaturahmi mempunyai tiga sisi yang sangat menguntungkan bagi kita.Pertama, memberikan nilai ibadah. Kedua, apabila dilakukan dengan kualitas akhlak yang mulia akan memberikan impersi bagi orang lain sehingga dikenang, dicatat, dan dibicarakan banyak orang. Ketiga, bahwa silaturahmi dapat memberikan satu alur informasi yang memberikan peluang dan kesempatan usaha.

10. Memiliki Semangat Perubahan.

Pribadi yang memiliki etos kerja sangat sadar bahwa tidak akan ada satu makhluk pun di muka bumi ini yang mampu mengubah dirinya kecuali dirinya sendiri. Betapapun hebatnya seseorang untuk memberikan motivasi, hal itu hanyalah sebuah kesia-siaan belaka, bila pada diri orang tersebut tidak ada keinginan untuk dimotivasi. Sebagaimana firman Allah SWT."Sesungguhnya Allah tidak merobah Keadaan sesuatu kaum sehingga mereka merobah keadaan yang ada pada diri mereka sendiri. dan apabila Allah menghendaki keburukan terhadap sesuatu kaum, 
Maka tak ada yang dapat menolaknya; dan sekali-kali tak ada pelindung bagi mereka selain Dia”. (Qs. Ar-Ra'd : 11).

\section{KESIMPULAN}

1. Islam memberikan dasar yang kuat tentang prinsip-prinsip seorang hamba dalam berkeja. Hal tersebut tergambar jelas dalam Al Quran dan Hadits bahwa kehidupan dunia bukanlah semata-mata berorientasi kepada ibadah akhitat saja namun ada amalan-amalan yang dapar menjaga eksestensi manusia dalam kehidupan dunianya. Tujuan akhir dalam etos kerja adalah menjaga kualitas dari sebuah pekerjaan karena dalam kegiatan tersebut terkandung makna amanah dan nilai ibdah.

2. Konsepsi Ekonomi Syariah merupakan metode untuk menguraikan makna ibadah dan mencari keridhaan Allah dalam bentuk amal keduniaan. Kegiatan ekonomi dinilai ibadah apabila amalan tersebut terbentuk atas dasar niat dan keikhlasan mencari ridha Nya Allah. Kualiatas kerja dapat dicapai apabila kualitas keimanan seorang hamba terjaga dari pendangan keindahan duniawi.
Kemudian untuk mewujudkan semua hal tersebut dibutuhkan pemahaman yang mendalam sebelum seseorang mengejakan sebuah pekerjaan. Kualitas kerja dapat meningkat apabila pekerjaan itu dilakukan dengan mengacu kepada nilai-nilai etika dan akhlak yang sesuai dengan tuntunan Islam.

\section{Saran}

1. Perlu kajian lebih mendalam dan waktu yang lebih banyak untuk menelusuri kajian tentang etos kerja. Sehingga esensi dari etos kerja dapat diungkap. Teori-teori yang mengantarkan pemahaman umat untuk bekerja tidak sematamata berorientasi kepada materi malainkan amal ibadah dan keridhaan Allah.

2. Dalam rangka menigkatkan kualitas kerja pada lembaga/tempat dimana seserang berkerja perlua diperbanyak kajian-kajian keislaman. Kajian-kajian tersebut dengan bertujuan untuk membuka pemahaman para pekerja tentang orientasi dari sebuah pekerjaan dan juga meningkatkan keimanan dalam beragama. Karene walau bagaimanapun sebuah pekerjaan 
tanpa dilandasi keimanan yang kuat akan tersebut kepada sifat-sifat kufur dan akhirnya membuat lupa sesorang terhadap tujuan hidup di dunia.

\section{DAFTAR PUSTAKA}

Abdul Munir Mulkhan, 1995, Perburuhan dalam Gerakan dan Pemikiran Islam, makalah tidak diterbitkan

Al-Hafidh al-Mundziry, 1969, Mukhtashar Shahih Muslim, 2 Jilid Kuwait: Wazarat al-Awqaf wa al-Syu'un al-Islamiyyah.

Al-Sayyid Abd alRahim Anbar alThahthawi, 1353,Hidayat al-Bari ila Tartib al-Ahadits al-Bukhary, Kairo: alMaktabat al-Tijariyah al-Kubra.

Betty R. Scharf, 1995, Kajian Sosiologi Agama, (terj.) Drs. Machnun Husein Yogyakarta: Tiara Wacana Yogya.

Budhy MunawarRachman, 2006, Ensiklopedi Nurcholish Madjid, Jakarta: Mizan Paradamina-CSL. Jalaluddin, 1996, Psikologi Agama, Jakarta: Rajawali Press.

Yahya Muhaimin,1993, “Islam dan Etos Kerja: Tinjauan Politik", dalam Abdul Basir Solissa, dkk (ed.),
Al-Quran dan Pembinaan

Budaya: Dialog dan Transformasi Yogyakarta: LESFI,

Jansen Hulman Sinamo, Guru Etos Indonesia, makalah tidak diterbitkan.

Komaruddin Hidayat, 1994, "Etika

Dalam Kitab Suci dan Relevansinya Dalam Kehidupan Modern: Studi Kasus Di Turki”, dalam Budhy MunawarRachman (ed.), Kontekstualisasi Doktrin Islam Dalam Sejarah, Jakarta: Yayasan Paramadina.

M. Bambang Pranowo, 1992, "Tarekat dan Perilaku” Ekonomi”, Pesantren, No. 1, Vol. IX,.

Ma'ruf Abdullah, 2011, Wirausaha Berbasis Syariah, Banjarmasin : Antasari Press.

Muhammad Tholchah Hasan, 2000, Dinamika Kehidupan Religius, Jakarta: Listafariska Putra.

Norman K. Denzen dkk, 2009., Terjemah Handbook Of Qualitaitive Research (Handbook Of Qualitaitive Research), Pustaka Pelajar: Yogyakarta.

Nurcholish Madjid, 1992, Islam Doktrin dan Peradaban, Jakarta: Paramadina. 
Volume 4 Nomor 1, April 2018

Nurcholish Madjid, 1994, Pintu-Pintu

Menuju Tuhan Jakarta:

Paramadina.

Prijono Tjiptoherijanto, 1988, Etos

Kerja dan Moral Pembangunan

dalam Islam, makalah tidak

diterbitkan.

Research (Handbook Of Qualitaitive

Research), Pustaka Pelajar,

Yogyakarta.

Richard C. Martin, 1982, “Understanding The Qur'an in

Text and Context", History of

Religions.

Robert N. Bellah, 1970, “Islamic Tradition and the Problem of Modernization" dalam Robert N.

Bellah, ed., Beyond Belief, New York: Harper and Raw.

Sri Edi Swasono, 1988, dkk., Sekitar

Kemiskinan dan Keadilan Dari

Cendikiawan Kita Tentang

Islam, Jakarta: Penerbit UI.

Taufiq Abdullah, 1979, Agama, Etos

Kerja dan Perkembangan

Ekonomi, Jakarta: LP3ES.

Toto Tasmara, 2002, Membudidayakan

Etos Kerja Islam, Jakarta :Gema Insani Press. 